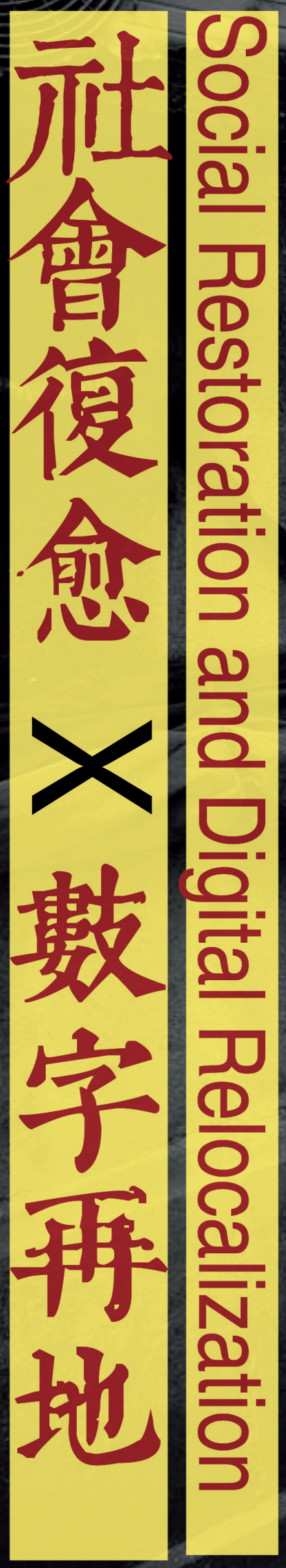

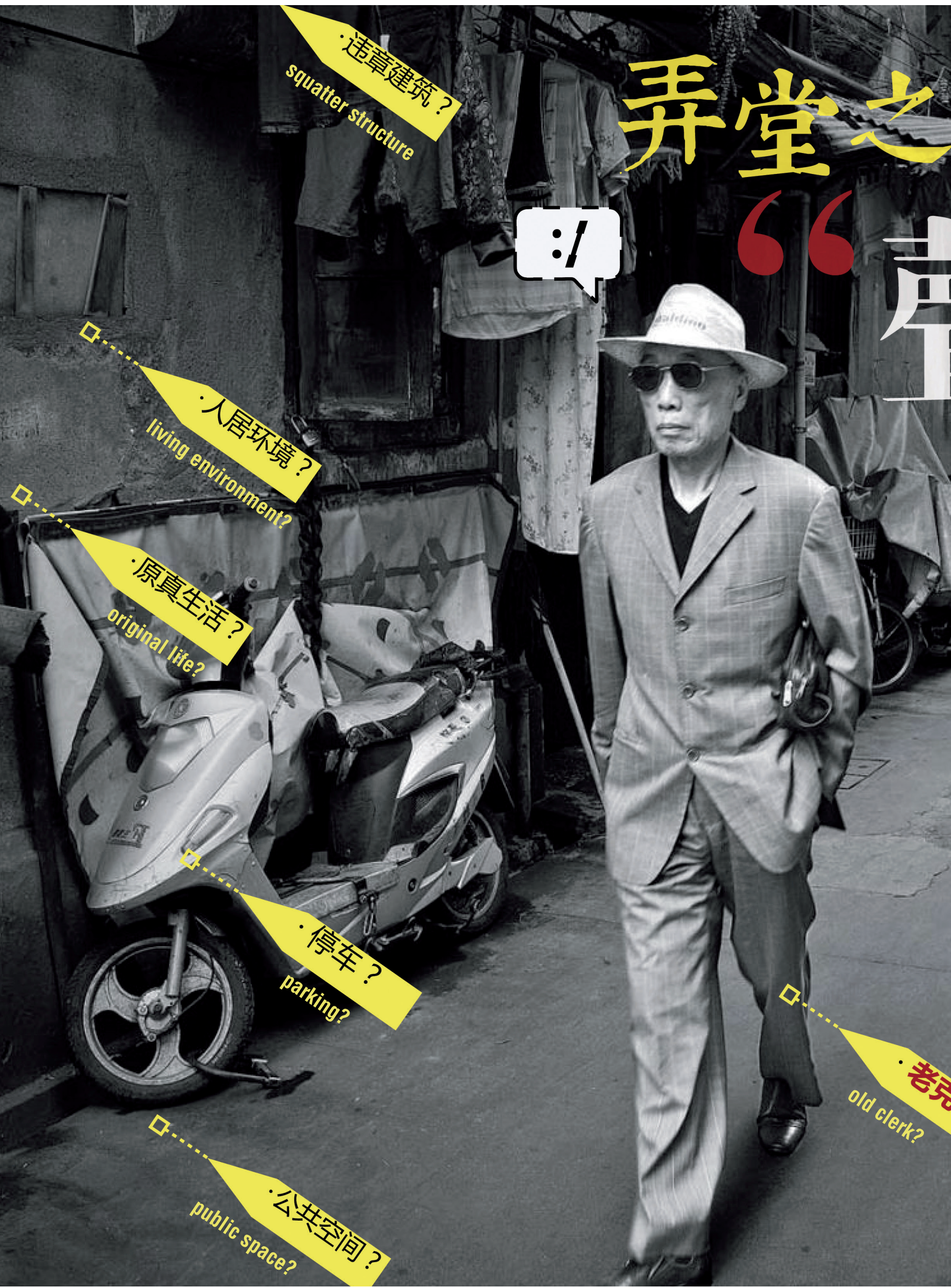




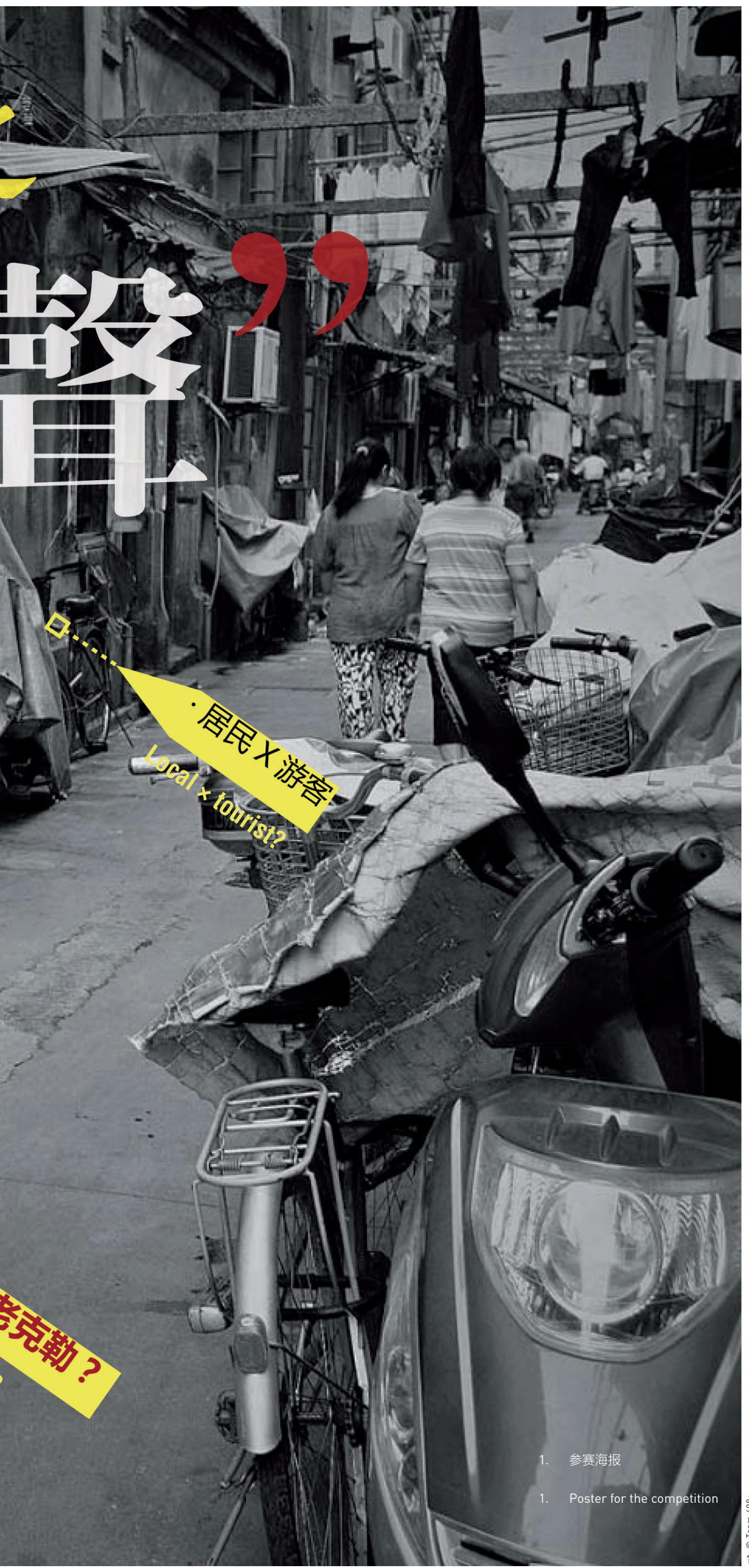

\section{社会复愈, 数字再地 一以大数据策略实现空间自组织 SOCIAL RESTORATION AND DIGITAL RELOCALIZATION - A BIG DATA STRATEGY FOR SPATIAL SELF-ORGANIZATION}

项目背景

上海市徐汇区衡山路一复兴路历史文化风 貌区（衡复风貌区）位于延安中路以南、重 庆南路以西, 面积逾 $7 \mathrm{~km}^{2}$, 是全市保护规模 最大、花园式住宅分布最集中、风貌特色保 存最完整的地区，堪称上海城市文脉的发源 地和承载区。2016年，上海市开展 “上海城 市设计挑战赛”，试图通过对大数据的分析 和运用, 为城市中待更新地区的转型提供创 新性的设计思路。衡复风貌区为此次大赛的 其中一处指定片区，笔者所在的“408研究 小组+”选取了这一片区展开研究。

设计构思

在城市更新的过程中，大数据的应用多 与城市治理和多元主体博栾相关。已有的研 究大多与城市治理相关一一尽管其中多为对 于还未真正实现的智慧城市的研究。相较而 言, 基于人类学调研方法将城市信息学维度 的数据应用于多元主体博弯方面的研究则明 显不足。这导致许多以城市更新为目标的数 据实践未能得到深入应用。

在整体保护较为成功的上海, 面对存

\footnotetext{
DO1:10.15302/J-LAF-20170307 |收稿时间 RECEIVED DATE / 2017-05-20 中图分类号 $/ \mathrm{TU}$ 文献标识码/ $\mathrm{B}$

摘要

本文介绍了408研究小组+在2016年“上海城市设计挑 战赛”中, 针对衡山路-复兴路历史文化风貌区的历史保护所 提出的方案, 并藉此强调了研究数据平台与使用者之间关系的 重要性。该方案主张复愈而非修复, 生长而非生产, 提倡从多 元主体角度去思考历史风貌区的原真性, 推动当下风貌区的保 护与更新。设计方提出架设 “漫步衡复” 和 “弄堂之声” 两大 应用平台, 通过将大数据融入城市治理来实现城市更新, 并力 图使数据参与平台与城市自组织和空间代理协调配合, 形成可 以持续发挥效用的共同体。

关键词

大数据；多元主体；自组织；城市更新；空间代理

\section{ABSTRACT}

This article introduces Team 408+'s design for the protection of the Hengshan Road-Fuxing Road Historical and Cultural Area in the 2016 Shanghai Urban Design Challenge, with the Areat in data platforms and their users. In promoting the historical and cultural protection, the design advocates remediation with spatial self-organization rather than restoration with physical development, and encourages multi-stakeholders' participation. This project also proposes two mobile applications, "Wandering in Heng-Fu" and "Voice of Alleys," to apply big data into urban management and to establish sustainable communities by harmonizing big data platforms with urban self-organization development and spatial management

Big Data; Multiple Stakeholders; Self-organization; Urban

Regeneration; Spatial Agency

整理 汪默英

译 姜芉孜 阿梅莉亚・詹森

EDITED BY Moying WANG

TRANSLATED BY Qianzi JIANG Amelia JENSEN
} 


\section{项目地址}

上海市徐汇区

项目面积

$7.75 \mathrm{~km}^{2}$

项目委托:

上海市规划和国土资源管理局

城市设计

408研究小组 +

项目负责人:

言语

指导老师:

徐腯青

策划: 言语、陈晨;

数据库搭建: 李易、屈信;

数据分析: 李易、屈信、刘江德、吴夏安、Aline

用户界面设计与情景设计：朱枫、宋海娜、吴越、郑婷,

效果图制作: 郭志滨、官诗菡、许可;

排版: 言语、黄舒晴、邱班中

项目时间:

2016年8 12月
量的风貌区保护与更新这一问题，就地原封 不动地保存未必一定是正确的。一方面, 由 于多元主体协商机制尚未完善, 渐进式更新 推进受限, 产权整合和变更成为了居民自组 织城市更新和城市治理的巨大阻碍; 另一方 面，尽管土地招拍挂制度形成的经济杠杆使 得政府可以大批量地整合地权，但往往会导 致驱离式的拆迁和暴力式的增容。

在幅员辽阔而又发展迅速的中国, 风 貌区保护与古城更新呈现出“魔幻现实主

\section{LOCATION:}

Xuhui District, Shanghai

AREA (SIZE):

$7.75 \mathrm{~km}^{2}$

LIENT

Shanghai Municipal Bureau of Planning and Land

Resources Administration

URBAN DESIGN:

Team 408+

PROJECT LEADER:

INSTRUCTOR:

Leiqing $X u$

\section{PROJECT TEAM:}

Scheme: Yu Yan, Chen Chen

Databases Establishment: Yi Li, Xin $Q$

Data Analysis: Yi Li, Xin Qu, Jiangde Liu, Xia'an Wu, Alin UI Design and Scenario Design: Feng Zhu, Haina Song. Yue Wu, Ting Zheng;

Rendering: Zhibin Guo, Shihan Guan, Ke Xu:

Graphic Design: Yu Yan, Shuqing Huang, Banzhong Qiu

DESIGN PERIOD:
义”：“地王”的区位与落后的生活服务配 套设施不符、“求拆”与迫迁的情况并存、 违建设施清除与自发性改造交锋。衡复风 貌区占据典型的地王区位, 继续强调就地 原封不动地保存最终会陷入居民过不好、 开发商拆不动、保护实践学者也陷入道德困 境的怪圈。

因此, 我们提倡复愈而非修复, 生长而 非生产。只有以多元主体为出发点去思考原 真性, 才会得出兼顾城市风貌、文化与空间

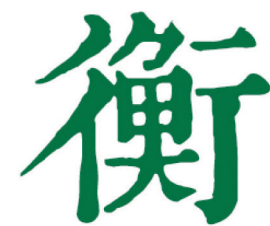

SUSTAINABLE

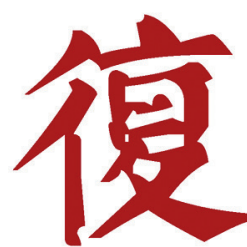

RENAISSANCE

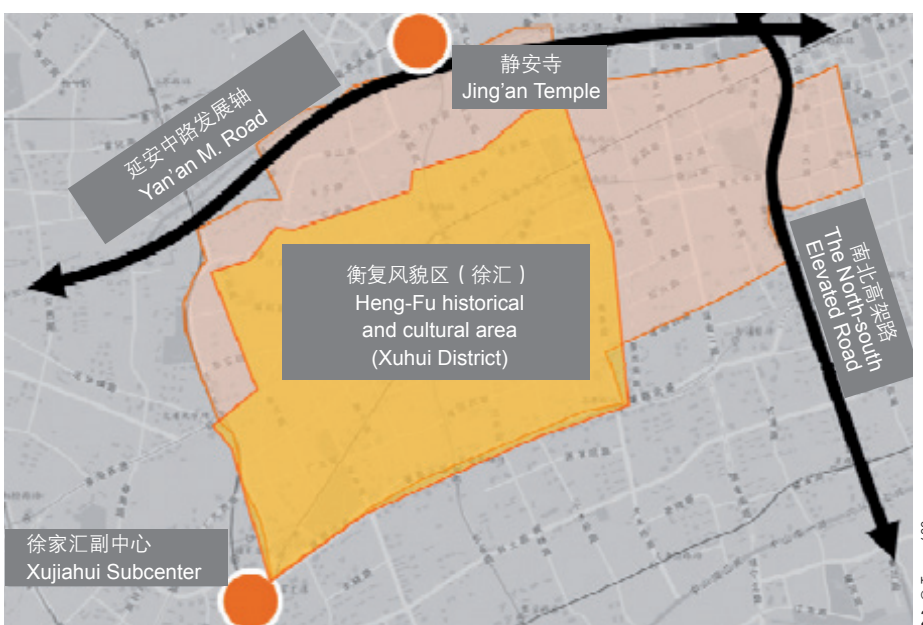

衡复风貌区区位图 里弄现状和存在问题 “生长的空间”

2. Location of the HengFu District

Existing conditions of the alleys in Shanghai "Growing space" and "Growing space" 
正义的解决方案, 使最终被保留下来的社会 文化焕发新的生命力。

同时, 那些由数据支撑的结构主义实 践, 如何介入颇具后结构主义语境的多元主 体博栾、产权落实中, 并在城市治理时避免 空间鸿沟、数据鸿沟乃至算法歧视 (即由数 学分析导致的不公正评价) 是另一个亟须明 确的问题。而共享平台的出现使缩小其中由 数据鸿沟所造成的差异成为可能。目前, 我 们已经为衡复风貌区建立数据资料库, 并面 向公众开放。在末来, 如果多方力量能够在 透明的讨论机制下联结共生, 例如在PPP模 式（政府和社会资本合作）下完成对社会空间的营造, 那么这些数据将切实助力城市 治理。

城市需要经过累积和生长来形成自组织 并完成空间实践。如果把以上问题综合起来 思考, 我们最终将探索出一条居民自组织 的渐进式城市更新之路、一种通过数据平 台上下结合的方式, 以及一个多方合作的社 群网络。

\section{数据处理}

在本方案中, 通过赋予数据不同的权重 并进行叠加, 可以得出改造意愿与优先级、 社区公共空间及人居环境评价等信息。结合 第六次全国人口普查数据加以计算, 可以得 到地块中与人口特性和空间特性相关的数 据, 二者经过加权计算后即可获得社区地块 的综合评价值。

例如，社区公共空间微更新的优先级主 要依据其空间䇻选评分、人因导向综合改造 评价及社区公共空间方差值三个数据计算得 出。其中, 空间䇻选评分主要由历史建筑数 量、绿地率、文娱/文创//邻里中心数量、空间 比例、可达性、人口密度6项指标计算获得; 人因导向综合改造评价由人群特征分数和居 住条件分数两部分构成, 可以通过赋予二者 不同的权重来调整优先级; 而社区公共空间 方差值则代表着不同区域中, 影响空间篮选 评分的六大要素的离散程度, 方差越大, 表 示该空间通过改善最短板项目而获得整体显
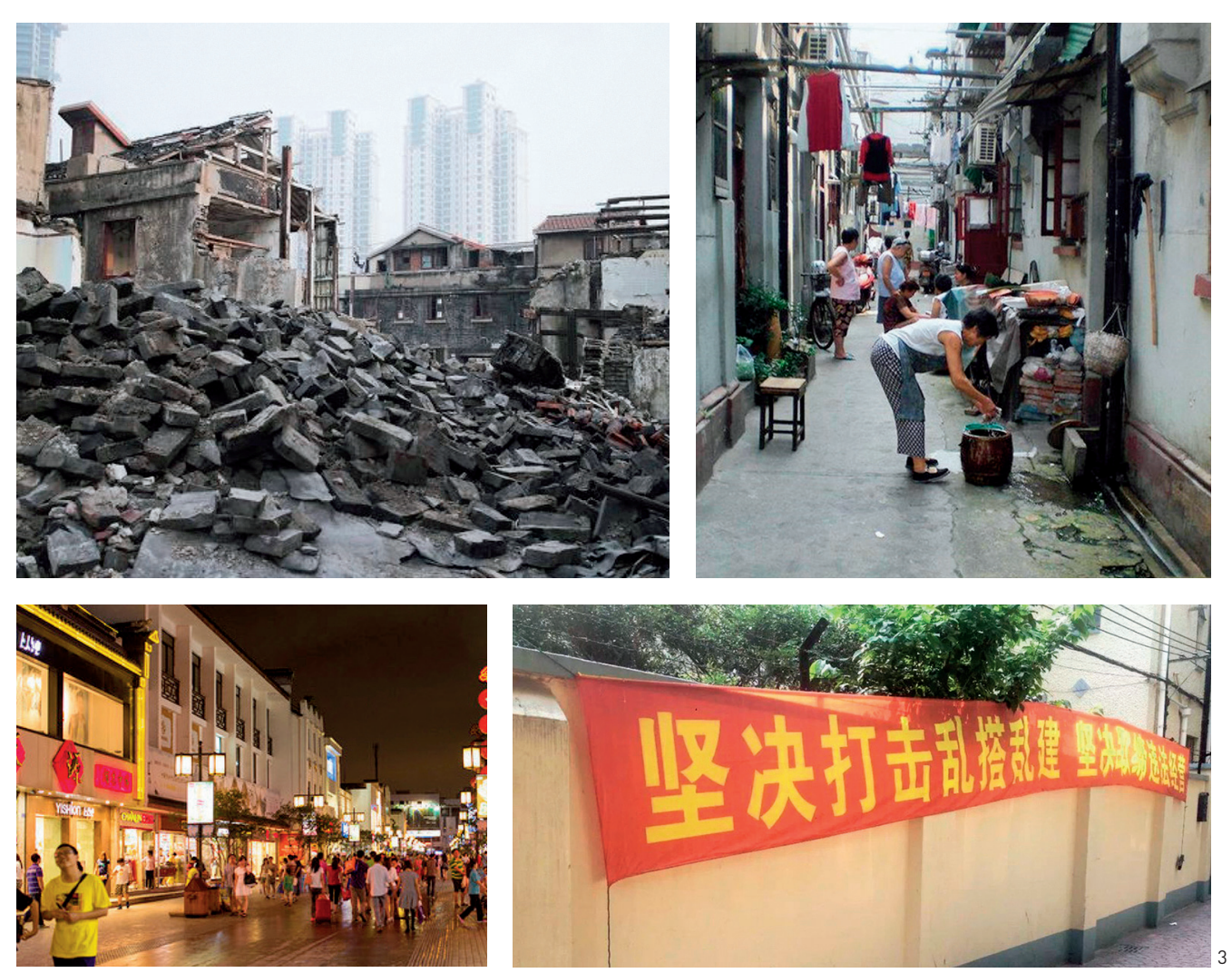

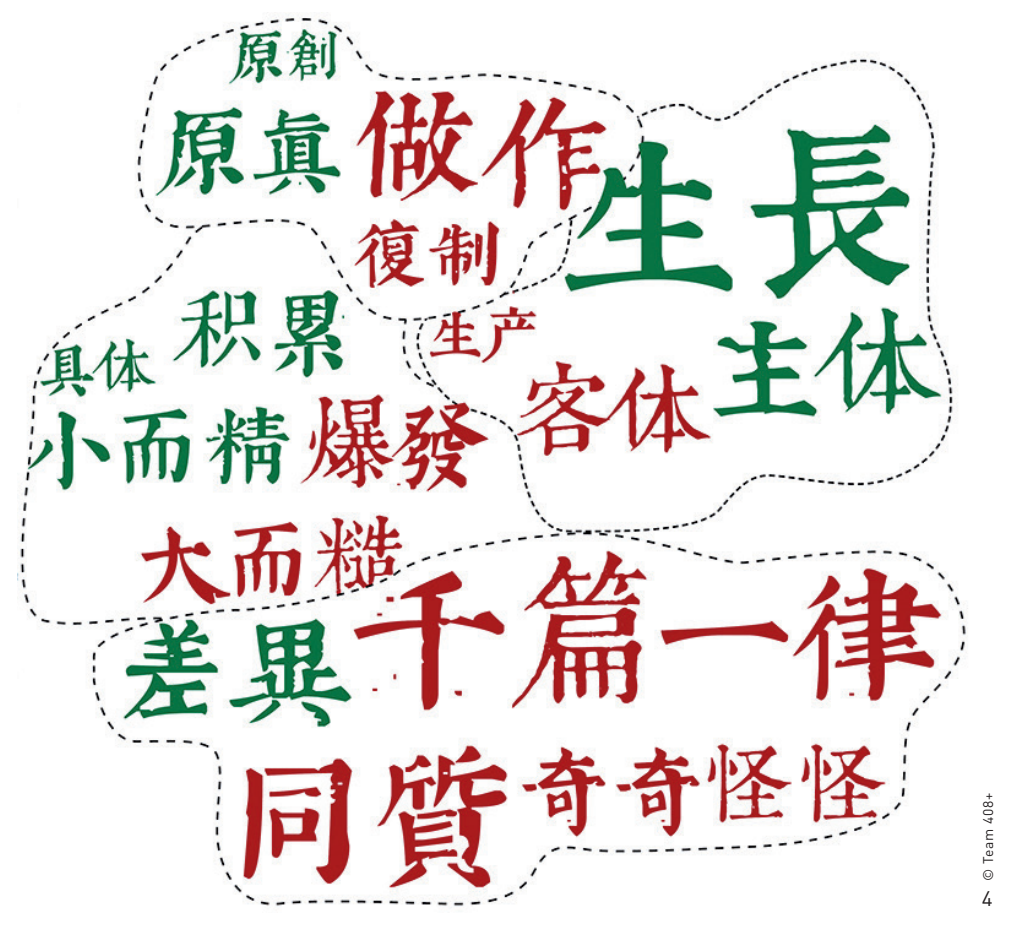


著提升的可能性越大。

此外, 根据空间句法理论, 通过对小型 公共空间周边的居住建筑、绿地等元素进行 加权处理, 即可获得亟待改造的公共空间的 范围。而通过大数据分析及权重计算, 亦可 获得步行/骑行环境综合评级、建筑屋顶改造 必要性评价等信息。

在制定规划策略和公共政策的过程中, 公平是一大重要议题。然而, 历史风貌区的 特殊性和社区主体的多元性, 使得这一议题 更加棘手。我们或许可以预见, 在人工智能 占领所有学科之后, 数据和信息上的公平才 会是最首要的公平。因此应当保证利用专业 而严谨的预处理和计算, 将大数据信息如实 呈现在数据平台上, 以供公众按需取用经过 适当可视化的数据。

\section{平台架构}

我们计划开发两款应用平台——“漫步 衡复” 和“弄堂之声”。“漫步衡复”服务 于衡复风貌区游客, 以提供旅游资讯为主。 “弄堂之声” 则旨在为衡复风貌区原住民提 供信息沟通平台及申请改造建设的渠道。

经过数据处理获得的改造优先级数据 将被主要运用于 “弄堂之声” 平台中的“自 宅报建” 和 “公共设施” 版块, 为居民选取 新建和改造目标提供参考, 同时也为审核报 批的政府部门提供批复和指导依据。而作为 信息点 ( $\mathrm{POI}$ ) 数据之一的空间评价数据, 则为“弄堂之声”平台中“便民查询” “社 区活动”及 “公共设施” 下的 “社区项 目”“片区项目”版块, 以及“漫步衡复” 平台提供支持, 包括通过网络分析计算优化 路径选择等, 主要将数据信息转化为可供使 用者获取的社区资讯。
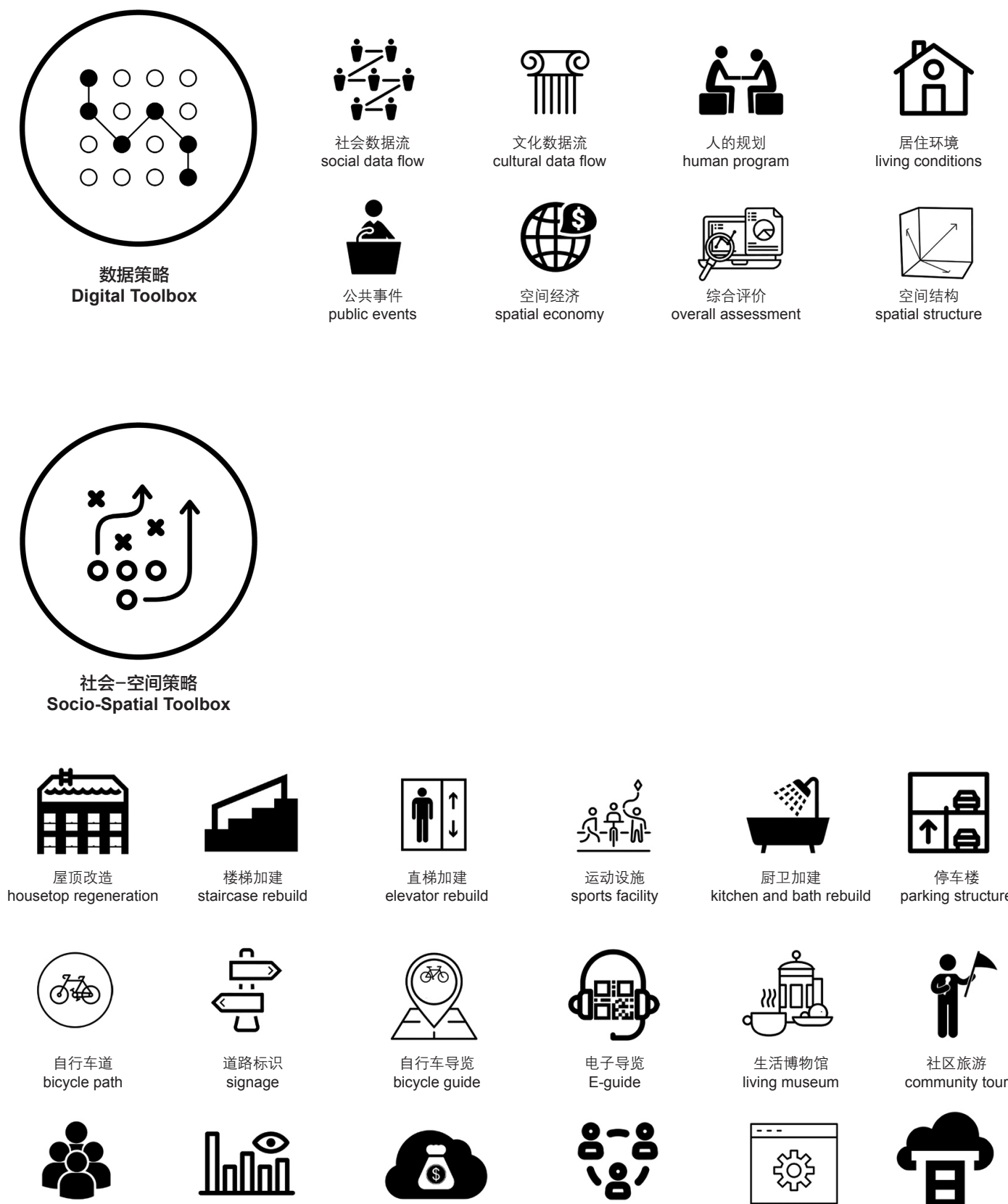

道路标识
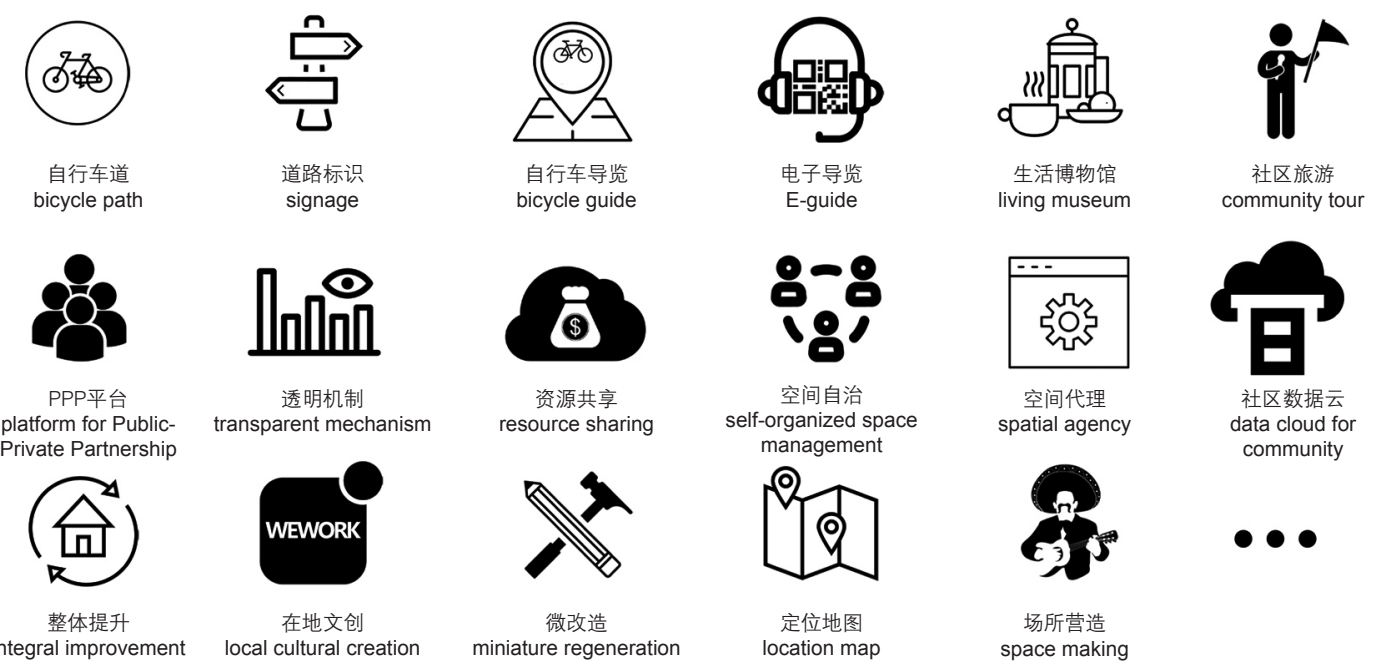


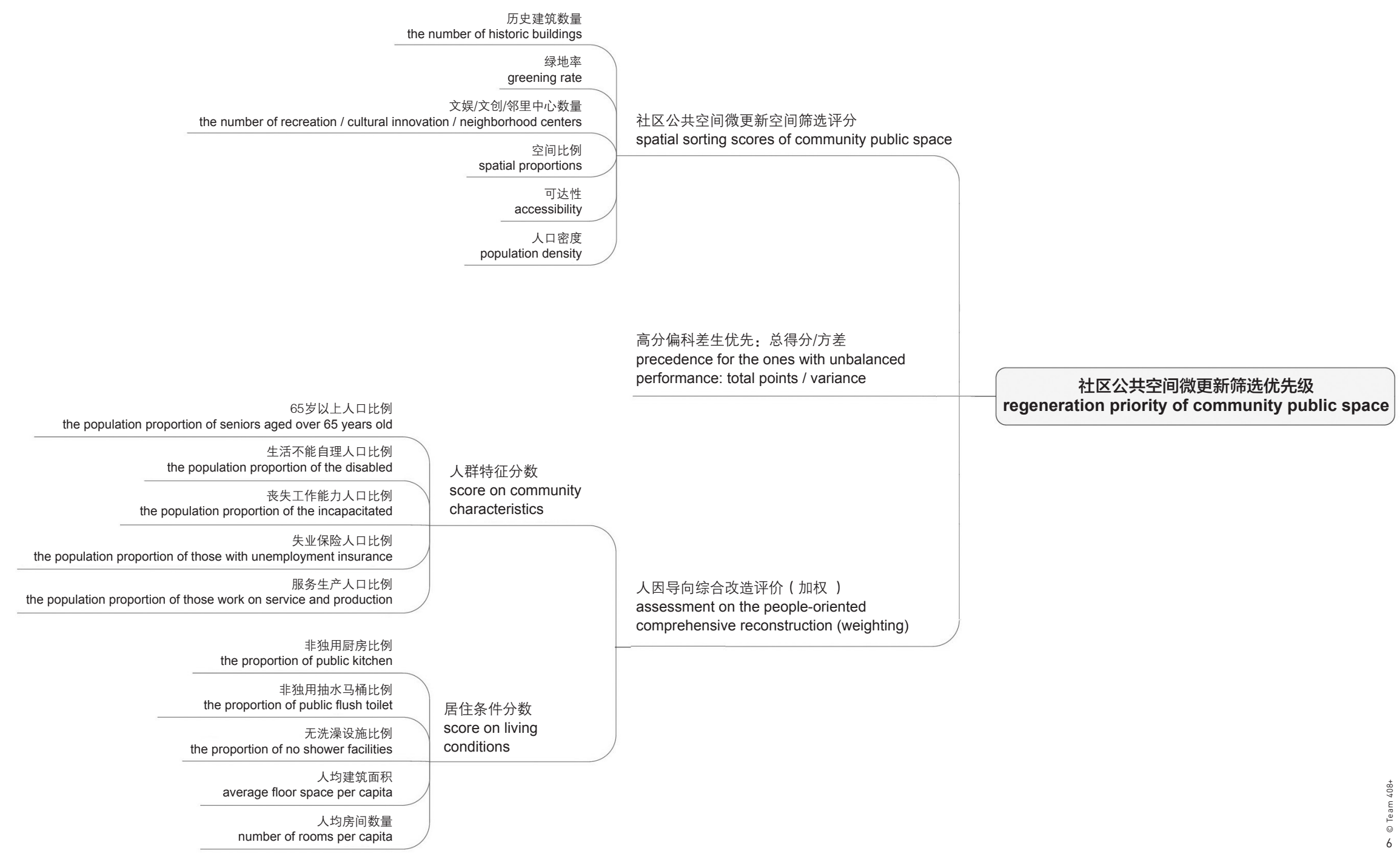

5. 数据策略与空间策略
6. 数据处理
5. Data and spatial
strategies
6. Data processing

6. Data processing
我们建议由政府或社会组织提供大数 据, 专业团队架设应用程序共享平台、处理 数据, 并给出专业性建议和建设方案, 最终 由衡复风貌区社区自组织等多方力量完成改 造和建设。在这种模式下, 很可能会派生出 新的公共服务产品与空间产品, 抑或是新的 社会一空间关系。在数据赋权的前提下, 行动 网络的社会关系将经历再生产与再组构, 通 过应用程序平台这一实践途径, 数据被赋 予针对规划核心问题的行动力, 并衍生出 将新的关系重新投射到建成环境的相关实践 之中。

\section{结语}

此次尝试意在突破原有的大数据研究范 式, 厘清从数据研究迈向社会-空间实践的 难点与可行性, 并提出以数据促进自组织更 新、技术赋权社会民主、自下而上地影响规 划实践的新途径。这意味着大数据以科学谨 慎又颇具批判性行动主义的角色, 参与到城 市更新乃至规划的核心过程之中。我们期待 实现技术变革对人类的赋权, 亦试图借助数 据唤起规划师和设计师对自身角色定位和空 间潜力的重新思考。LAF 


\section{Background}

The historical and cultural area of

Hengshan Road-Fuxing Road (Heng-Fu for short) in Xuhui District, Shanghai is located at the south of Middle Yan'an Road and the west of South Chongqing Road, covering of an area of over $7 \mathrm{~km}^{2}$. It is regarded as the core cultural area in the city for being the largest historical area with the most densely distributed garden houses and the best-preserved historic features. In 2016 , the Shanghai Urban Design Challenge was held to stimulate innovative design ideas for urban renewal with the application of big data. Team 408+ proposed their research on the Heng-Fu area, one of the study cases in the competition.
7. 大数据可视化

基于社区中心性对社区公 情况下, 对公共空间政造 优先级的图示。 共空间进行挑选，得到的
Big data visualization Processed priorities of open space based on different purposes and value orientations after selecting community public spaces accordin to community centrality.

\section{Concept}

In the process of urban renewal, the big data is often applied to assist urban management and to balance the interests of multiple stakeholders. The most current researches focus on the former,

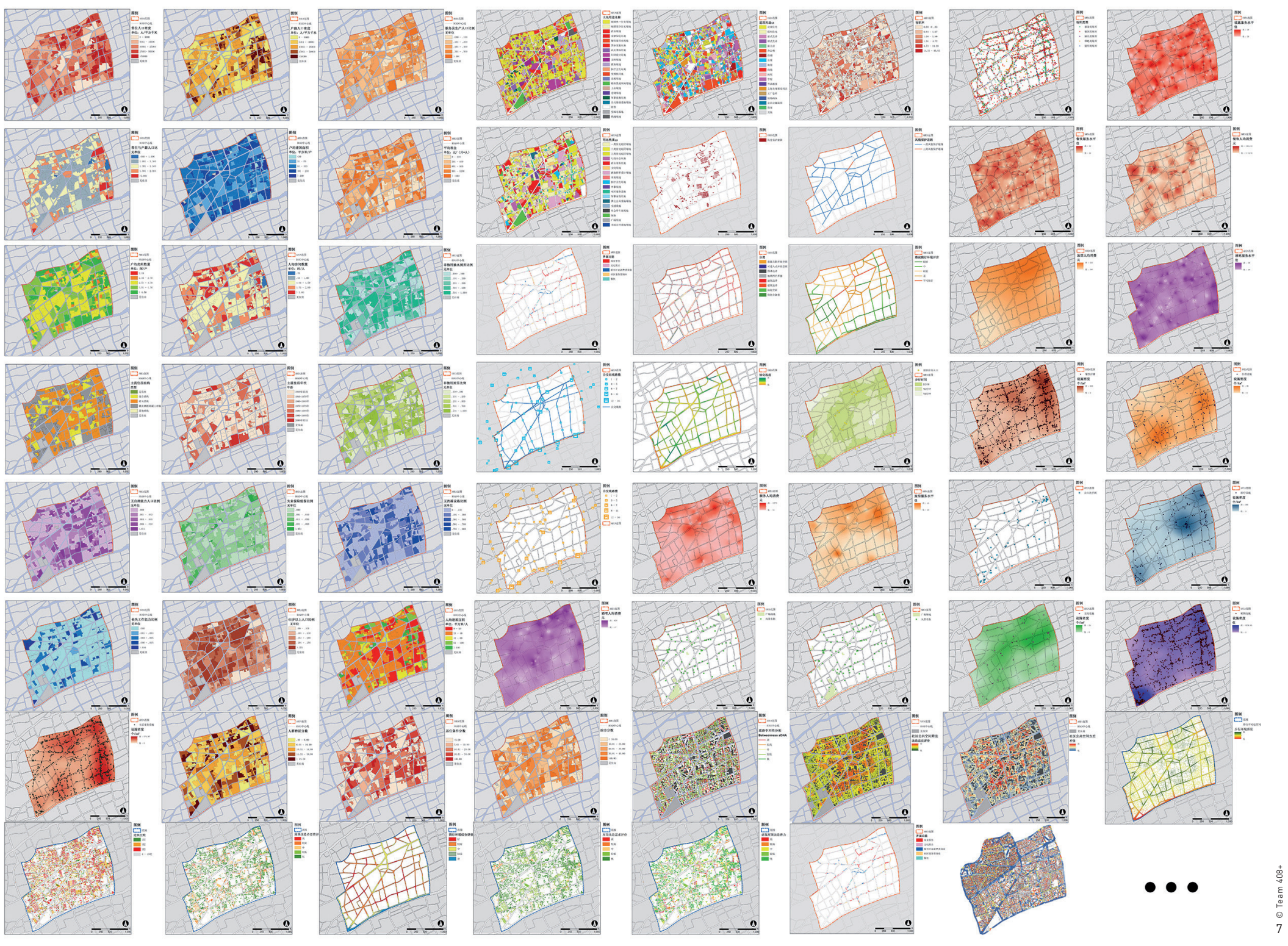



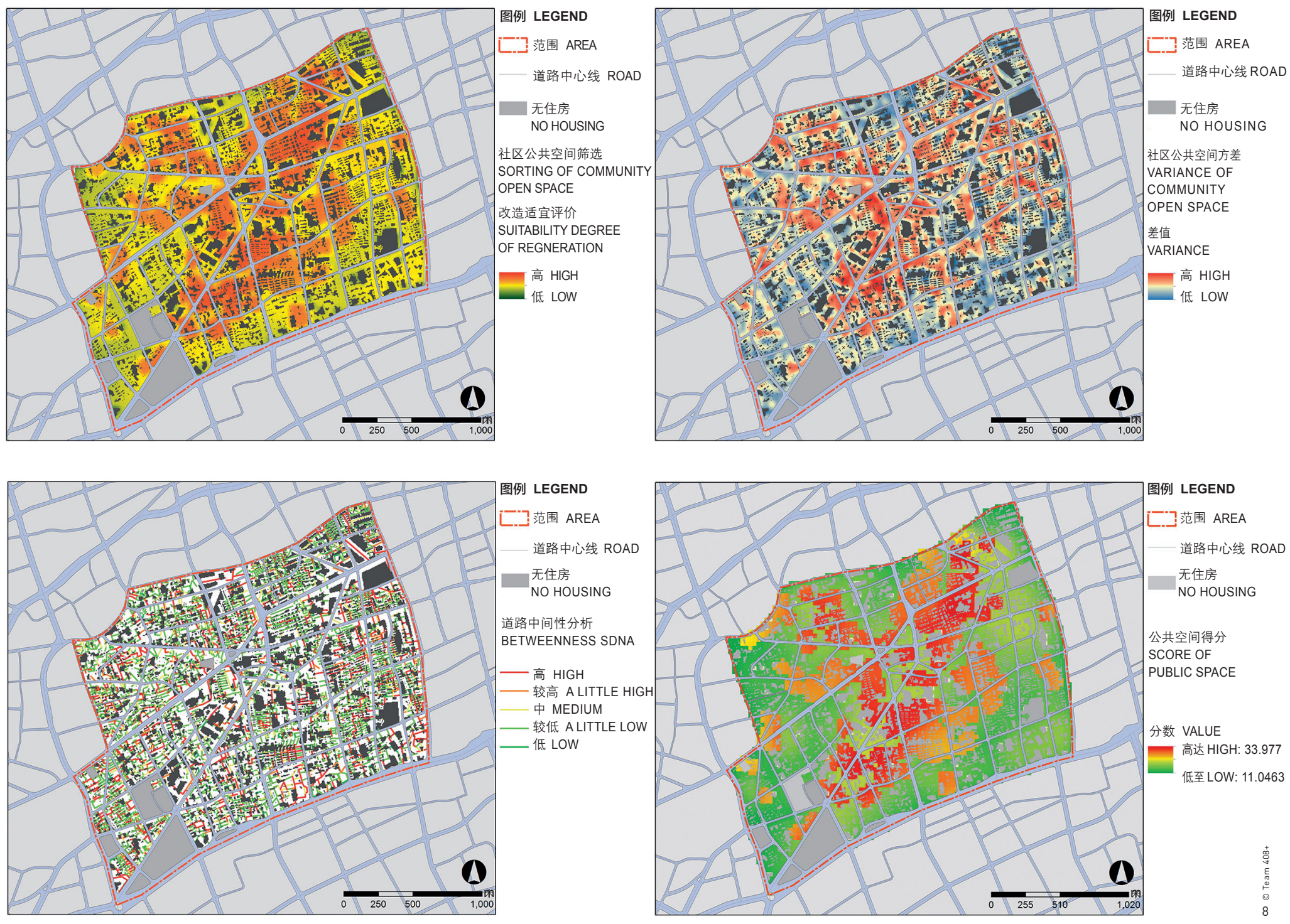

though a majority of which concern on the management of "smart cities," a vision not yet achieved. However, few studies have addressed how urban information can be applied in the latter through anthropological research. As a result, many urban renewal practices based on big data could not essentially contribute to the issues on urban management.

Shanghai, a city with sound overall heritage protection, has to face the issue of the protection of the historical areas with no changes that is not necessarily correct.
On the one hand, the incomplete negotiation mechanism for multiple stakeholders has been an obstacle for the integration and transfer of property which is the key to urban self-organization and -remediation in incremental urban renewal. On the other hand, although the transfer system of the right to use of land resources, including bidding, auction, listing, and agreement, allows the government to consolidate landownership, it often leads to forced resettlement and an unhealthy increase of floor area ratio. 
历史体验型

historical experience
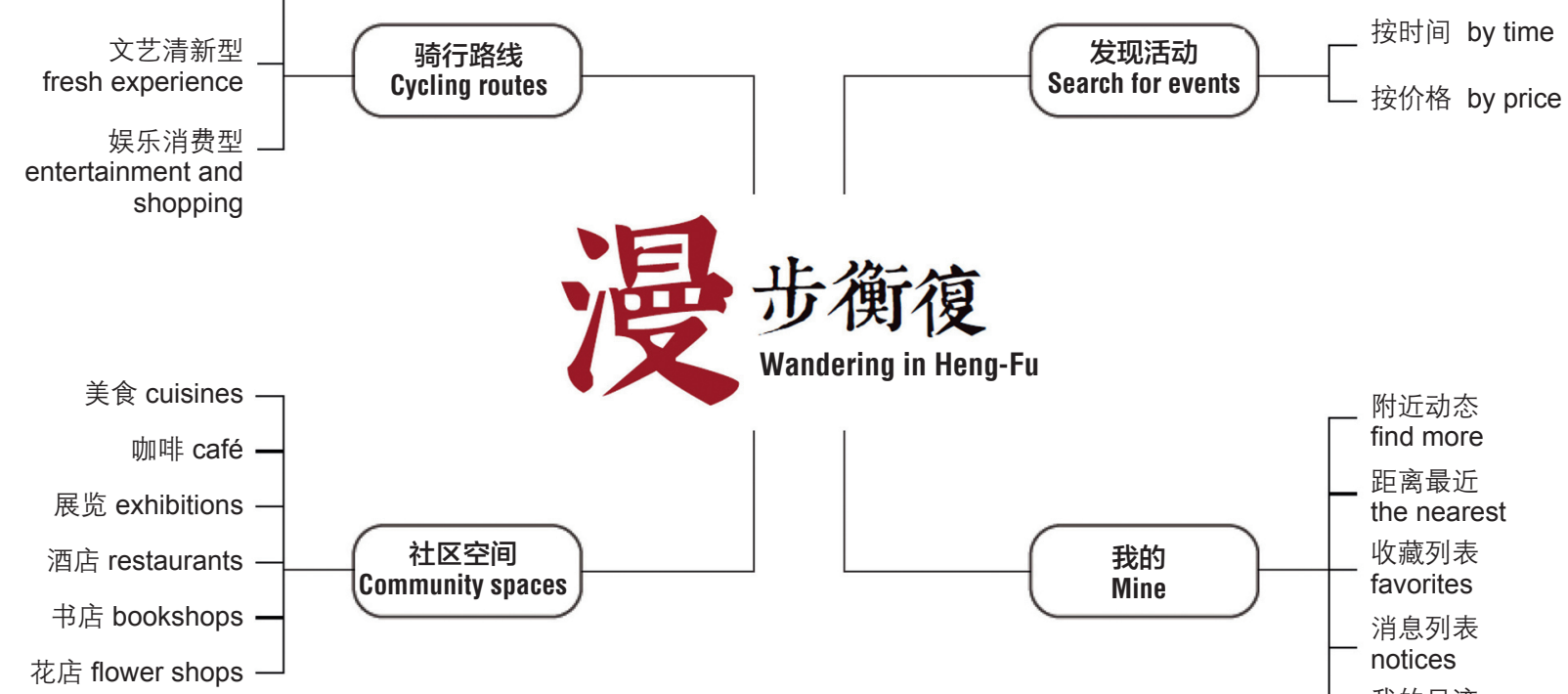

步衡復

Wandering in Heng-Fu
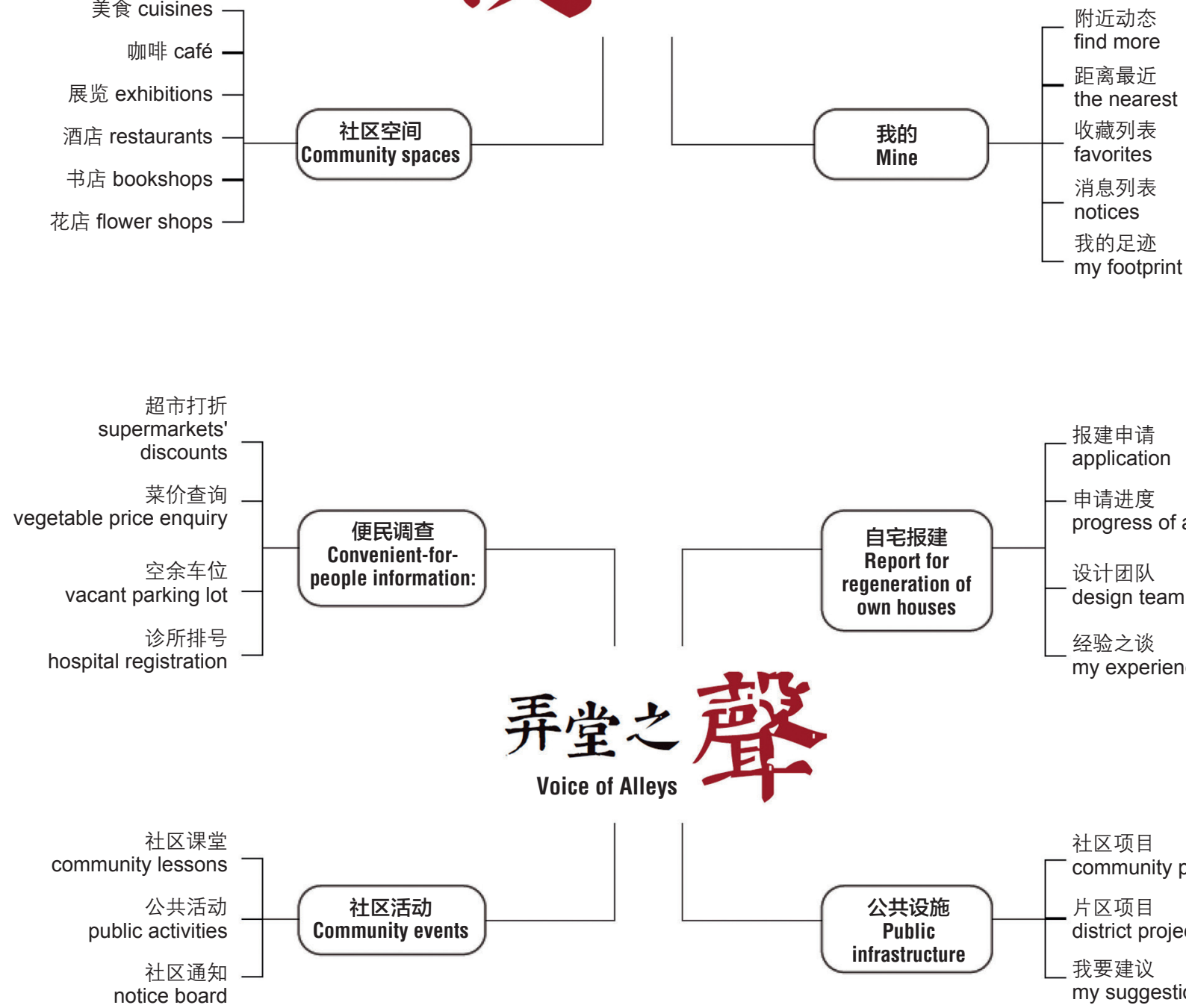

报建申请

application

一申请进度

progress of application

设计团队

design team

经验之谈

my experience

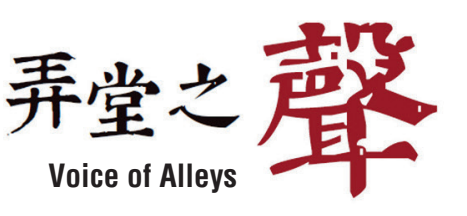

own houses

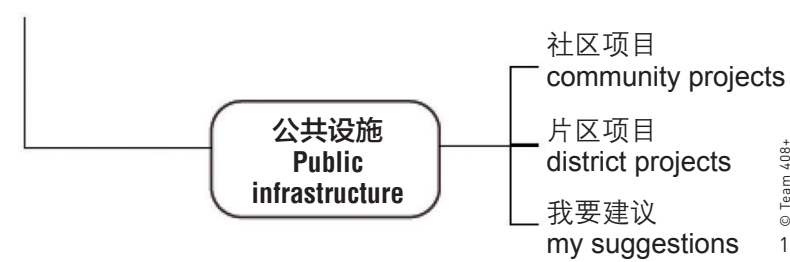

regeneration of
China is vast in territory and rapid in development, where the fact of historical protection and urban renewal is a kind of magical realism: the development of top-bidding land parcel lacks supporting infrastructure updates; some neighborhoods are urgently requested for resettlement while some are being forced eviction; and the demolishment of squatter structures coexists with self-organized regeneration. Being a typical top-bidding land parcel, the Heng-Fu area cannot be protected through a completely untouched way, otherwise which would not contribute to the improvement of living standards, the promotion of urban renewal, or the research of heritage conservation at all.

Therefore, we advocate remediation with spatial self-organization rather than restoration with physical development. Only with multiple stakeholders' participation, could we get solutions that take into account the city's identity, history and culture, and spatial justice in order to create a greater vitality of the preserved social culture.

Meanwhile, other problems arise, including how could the structuralism practices supported by data-based research contribute to the multistakeholder participation and property ownership clarification which are featured with post-structuralism, and how could it help avoid spatial gaps, data gaps, and even algorithmic discrimination lunjust evaluations caused by mathematical analysis) in urban management.

Fortunately, the emergence of the sharing platforms makes it possible to narrow down the information discrepancy resulted from digital gaps. At present, a database of the Heng-Fu area has been established and is open for public use. We expect a more efficient data-based promotion of urban management with multi-stakeholder participation through a transparent mechanism, such as the socio-spatial 
development through a Public-PrivatePartnership.

Cities need to realize selforganization with more practices and better development. Taking a comprehensive consideration of the city as whole, we will be able to develop an incremental way of urban renewal for community management, data platforms to bridge the gap between authorizations and citizens, as well as a collaborative network community.

\section{Data Processing}

The willingness and priority of urban renewal, as well as the quality of community public space and living environments, can be evaluated with data weights. Accordingly, an overall evaluation value of a community can be generated from a weighted calculation of the data about the population and spatial characteristics, sourced from the sixth national census.

For example, the priority of the microregeneration of community public space can be identified with spatial evaluation score, people-oriented assessment, and the variance of the calculated results about community public space. Respectively, 1) the spatial evaluation score is mainly based on 6 factors: the number of historic buildings, greening rate, the number of recreational spaces / cultural and innovational spaces / neighborhood centers, spatial proportion, accessibility, and population density; 2) the people-oriented assessment is based on the scores on both the population characteristics and living conditions, and the regeneration priority can be identified with various weights; 3 ) the variance of the calculated result about community public space represents the discrete degree of the mentioned 6 factors in different regions. The larger the value
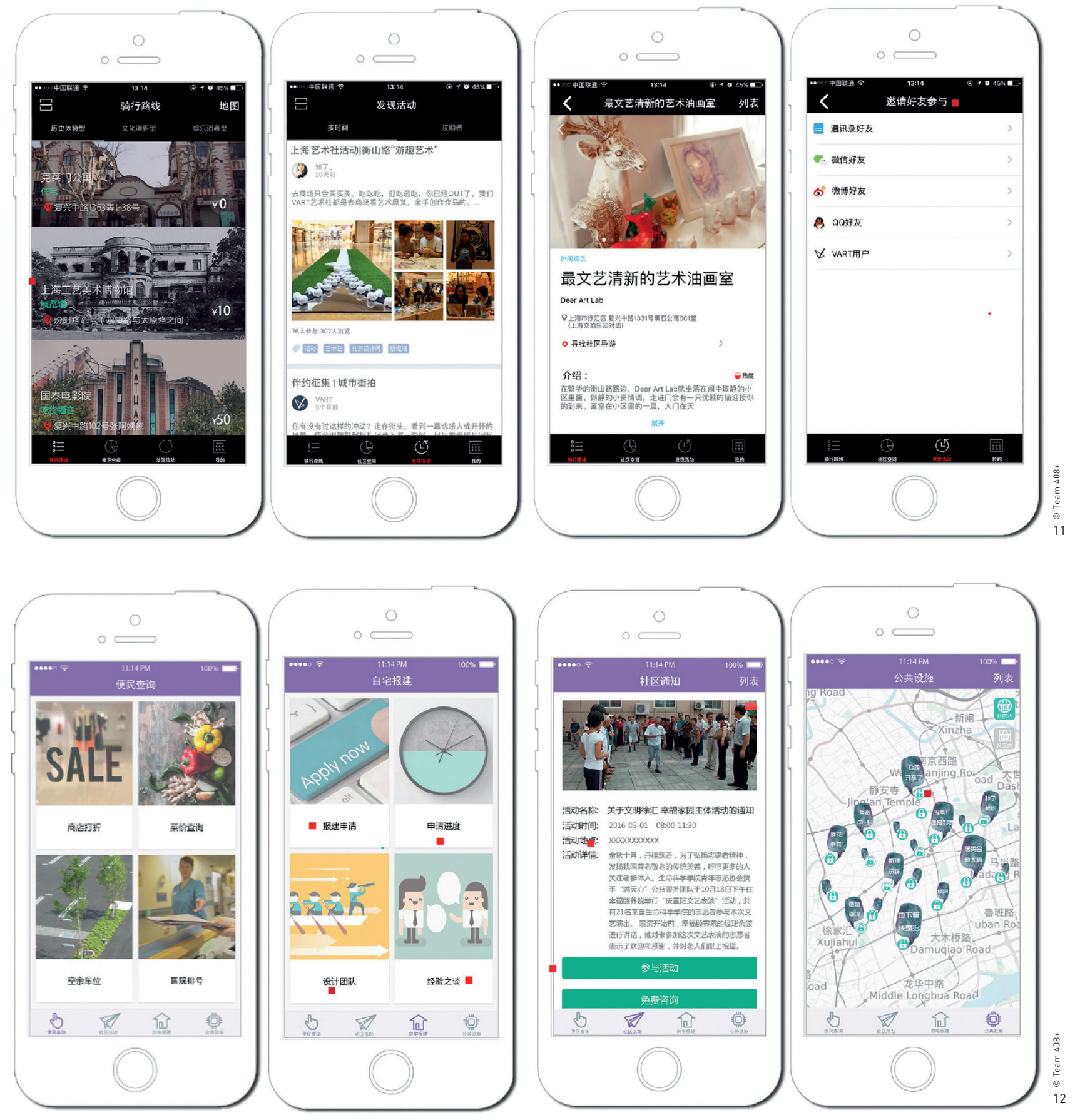

Framework of the "Wandering in Heng-Fu" Wandering in Heng-Fu"
Framework of the "Voice of Alleys"

11. Mobile pages of the "Wandering in Heng- $\mathrm{Fu}^{\prime}$ 12. Mobile pages of the "Voice of Alleys" 

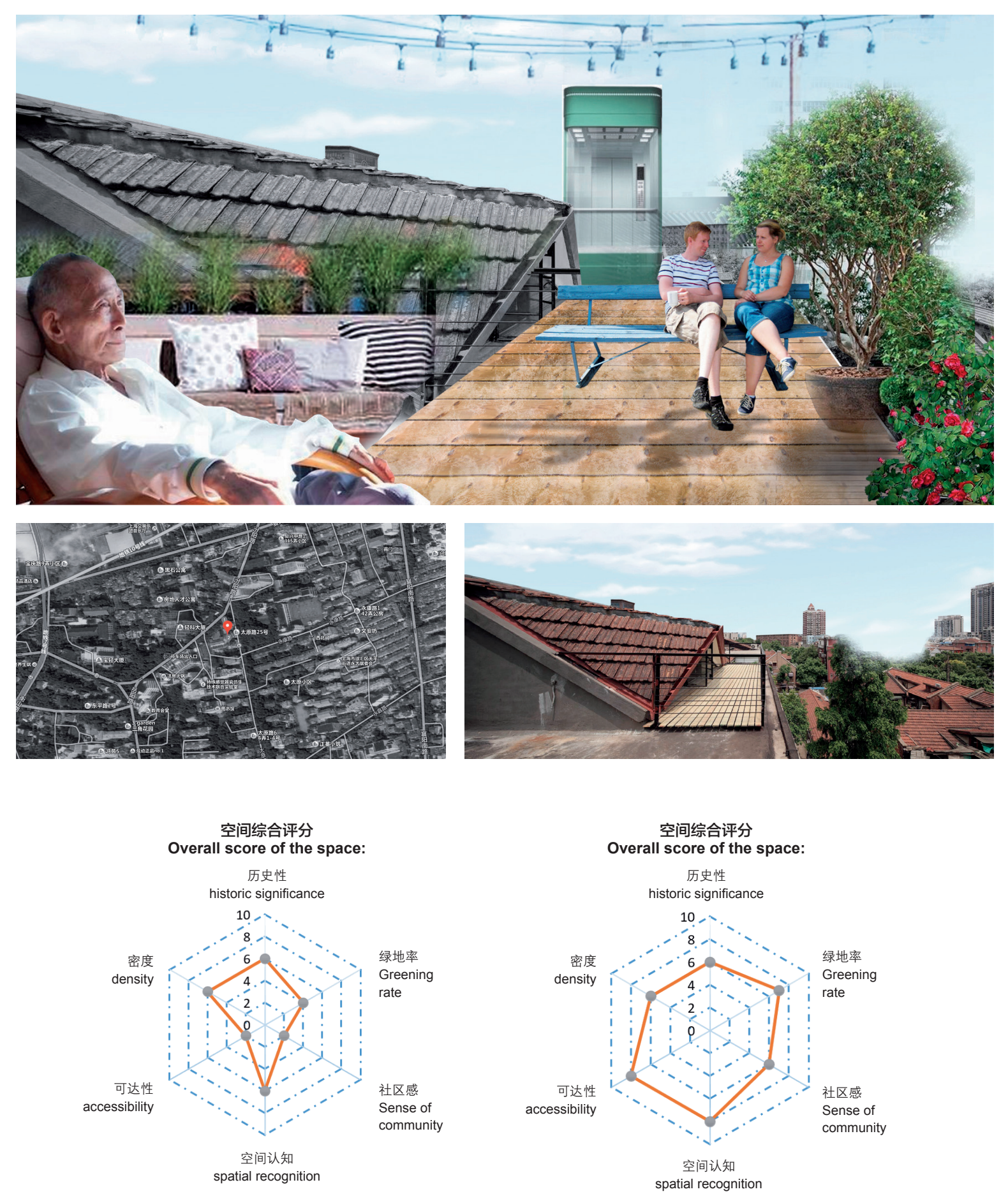

改造前

Before regeneration

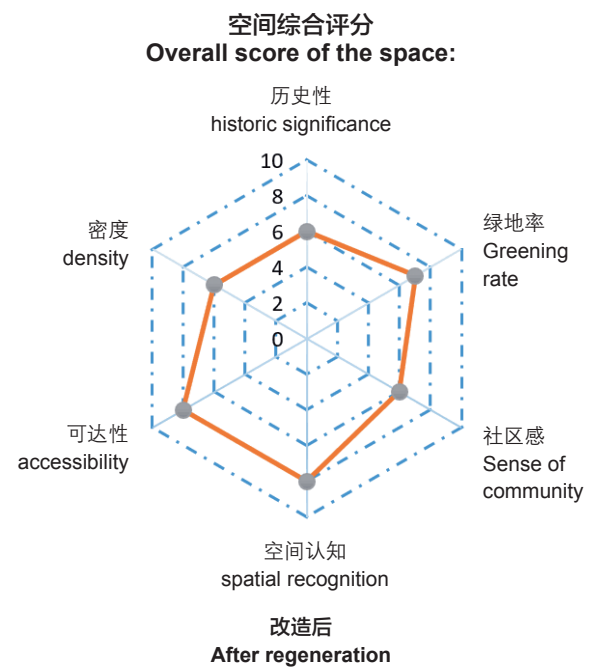

住户信息：普通上班族

Information of the house-owner: Office staff

可定义功能: 住户共享社区活动空间

Proposed function: Shared activity space for the community

门牌号: 太原路 56 弄1-4号

House number: No. 1-4, Alley 56, Taiyuan Road is, the more possibly the space can be improved.

In addition, according to the theory of Spatial Syntax, the boundaries of the public space which need to be urgently improved can be identified with weights concerning its surrounding residential buildings and green spaces. Moreover, the information such as the overall rating of the walking / cycling environment and the necessity evaluation of the rooftop rebuild can also be generated by big data analysis and weighted calculations.

Due to the distinctiveness of the historical areas and the participation of multiple stakeholders, it becomes more difficult to achieve spatial justice, which is important in formulating planning strategies and public policies. Predictably, the justice on data and information will be the primary equitable agenda when artificial intelligence becomes more prevalent. Therefore, the professional and rigorous pretreatment and computing of the big data should be guaranteed to accurately present the results and to ensure the big data visualization could efficiently serve the public through open data media.

\section{Framework of Public Data}

In this project, we proposed two applications - "Wandering in Heng-Fu," which serves tourists by providing travel information about the Heng-Fu area, and "Voice of Alleys," which is an interaction and communication platform to the local dwellers, and a channel for construction or rebuild application.

The sections of "Self-Construction" and "Public Facilities" in the "Voice of Alleys" publish the information of the regeneration priorities which inform the local residents' self-construction and-regeneration, and also help the governments approve the applications. 
Meanwhile, as part of the Point of Interest (POI) data, the spatial evaluation information supports both of the two applications by providing various services, such as the optimized touring routes and community news.

Ideally, the big data should be provided by the authorities and social organizations, and be processed and shared by open platforms (including mobile applications) which are operated by professional teams with the capability to provide practicable advices; eventually the construction and renewal can be implemented by the community organizations in the HengFu area. In this way, new types of public services, spatial products, and socio-spatial relationship might be created. The network of social relationships will be reproduced and reorganized through the application of big data. Thus, we are able to address the issue concerning urban planning with the assistance of mobile application platforms, which will lead related practices to establish new social relationships in the built environment.

\section{Conclusion}

In this project, the design attempts to break through the traditional paradigms of big data research, to identify the difficulties and to seek for the possibilities of translating data analysis into sociospatial practices. It also puts forward some new approaches to promote self-organized urban renewal and regeneration with big data, to improve social democracy with information and intelligence technologies, and to enhance citizens' rights on planning practices, in which big data offers scientific and critical supports. It is expected that with the technological innovation, urban planners and designers can better understand their roles and the potentials of spatial regeneration with the help from big data. LAF
13. “弄堂之声” 中的供选 改造建议

13. Suggested regeneration strategies generated by the "Voice of Alleys"
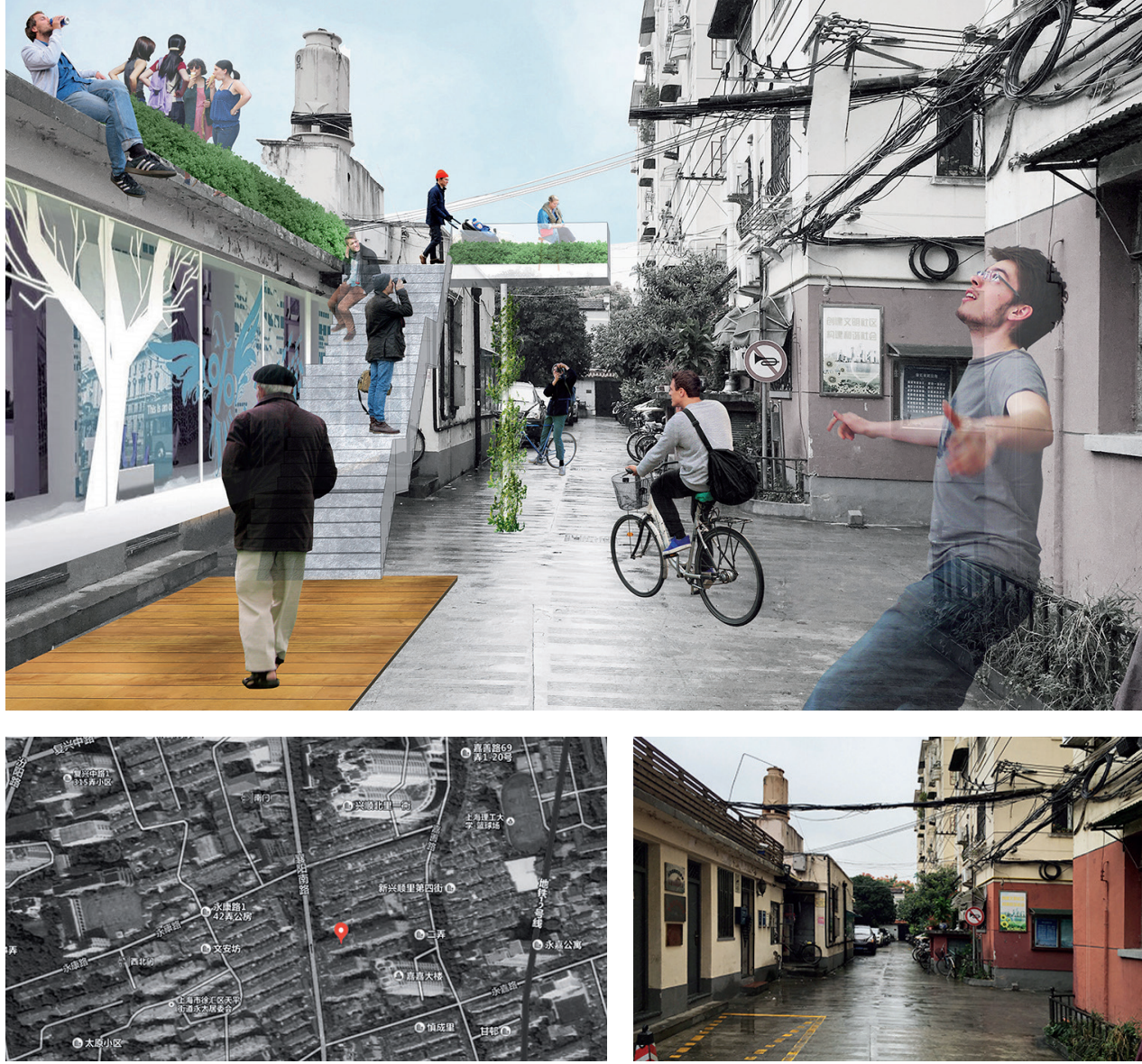

空间综合评分 Overall score of the space:

历史性

historic significance

$10 \cdots$

8

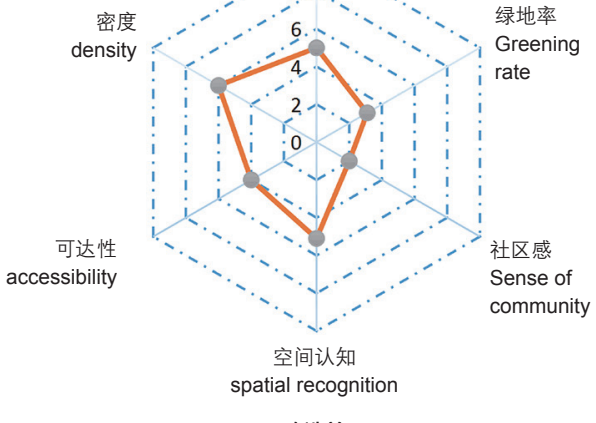

改造前

Before reger

评价: 街道较为拥挤, 空间利用率低, 街道缺乏停留性。 Evaluation: Crowded street with low utilization of space and lack of space to rest.

推荐改造策略：建筑外立面改造，视觉效果上扩宽街道; 增设 连接屋项的交通空间, 以提升交通功能和社交功能; 屋顶改造。 Recommend regeneration strategies: The openess of the streets is improved through facade design; adding transport space linking the roofs to improve transporting and social functions; rooftop remodeling

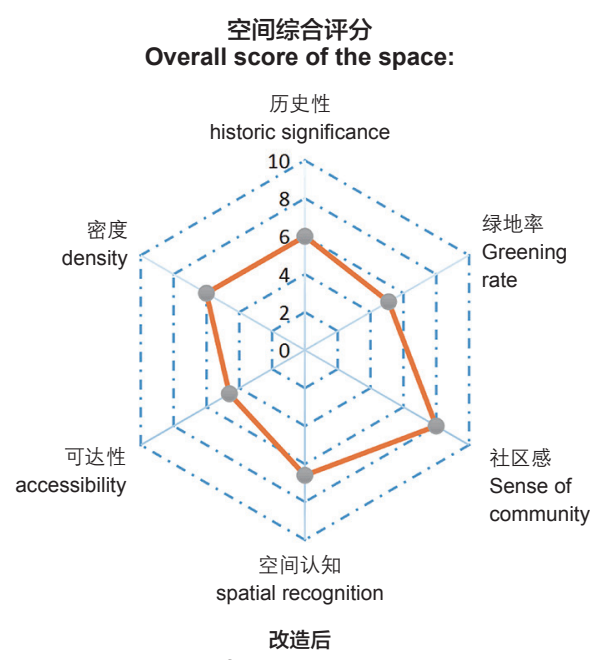

After regeneration
住户信息：居委会工作人员

Information of the house-owner: A staff member of

neighborhood committee

可定义功能: 公共社区活动空间

Proposed function: Public space for community activity

门牌号: 襄阳南路285묵

House number: NO. 285, South Xiangyang Road 